\title{
ANTIOXYDANT SYSTEM IN RATS' LIVER AND SKELETAL MUSCLES DURING EXPERIMENTALLY-INDUCED DIABETES AND ITS CORRECTION WITH CHROMIUM AND ZINC CITRATES
}

\section{Slivinska O. M., Iskra R. Ya.}

Diabetes mellitus is an endocrine disease that occurs as a result of an absolute or relative insulin deficiency, which leads to the defection of all types of metabolism. The appearance of this disease is predetermined by the influence of various exogenous, immune, endocrine and genetic factors or by their combination ${ }^{1}$. Regardless of its mechanism, the insulin deficiency leads to carbohydrates metabolism disorders at the first place, which leads to hyperglycemia. Glucose accumulation in blood leads to glycolysis and TCA intensification that results in an intensified work of electron transport chain in mitochondria. A membrane potential rises to a critical point that causes a block of a III mitochondrial complex, an electron from coenzyme-Q10 passes on to an oxygen molecule and a superoxide anion $\left(\cdot \mathrm{O}_{2}\right)$ is being formed ${ }^{2}$. In a state of hyperglycemia a mitochondrial superoxide dismutase (Mn-SOD) cannot cope with the excess of the superoxide anions and the oxidative stress begins. Superoxide anion converts to the hydroxyl-radical, hydrogen peroxide and peroxynitrite after interaction with other compounds ${ }^{3}$. The oxidative stress goes along with proteins nitrification, lipids peroxidation, DNA fragmentation, changes of cell signaling, activation of PARP-1, which results in metabolism and mechanisms of cell signaling disorders that are typical for diabetes complications ${ }^{4}$. As a result of pathological changes that occur under the condition of diabetes a lower glucose intake from blood, a local decrease of intracellular glucose reserve in a form of glycogen and triacylglycerides, an energetic depletion of the organism are seen. Altogether it leads to energy substrates deficiency that directly correlates with defense systems efficiency, in particular of the antioxidant one ${ }^{5}$. The antioxidant defense system controls

\footnotetext{
${ }^{1}$ Кузишин О.В., Ковалишин Н.В., Алмашина Х.В. Біохімія цукрового діабету: 1. Теоретична частина (огляд). Медична хімія. 2010. С. 74-115.

${ }^{2}$ Brownlee M. The pathobiology of diabetic complications: a unifying mechanism. Diabetes. 2005. No. 54 (6). P. 1615-1625. DOI: 10.2337/diabetes.54.6.1615.

3 Дрель В.Р. Основні механізми виникнення та розвитку діабетичних ускладнень: роль нітративного стресу. Biol. Stud. 2010. № 4 (2). P. 141-158 DOI: https://doi.org/10.30970/sbi.0402.085.

${ }^{4}$ Pacher P., Beckman J.S., Liaudet L. Nitric oxide and peroxynitrite in health and disease. Physiol. 2007. No. 87 (1). P. 315-424. DOI: 10.1152 / physrev. 00029.2006.

${ }^{5}$ Martyn J.A., Kaneki M., Yasuhara S. Obesity-induced insulin resistance and hyperglycemia: etiologic factors and molecular mechanisms. Anesthesiology. 2008. No. 109 (1). P. 137-148. DOI: $10.1097 /$ ALN.0b013e3181799d45.
} 
and restrains all stages of free radical reactions starting with their initiation and up to the hydroperoxides and malondialdehyde formation ${ }^{6}$.

Since the diabetes mellitus is a genetically predetermined disease, preventive measures to postpone the onset of the disease or to avert its appearance are especially important for people from risk group. That is why it is so important to evaluate role of some microelements in diabetes prevention. In particular, it is known that zinc plays an important role in insulin synthesis, accumulation and release by $\beta$-cells in pancreas, while its synergist chromium activates insulin receptors on cell membranes.

Therefore, the aim of our research was to establish the effect of chromium and zinc citrates on the functioning of antioxidant system and on the content of lipid peroxidation products in rats' tissues under the condition of experimental streptozotocin-induced diabetes mellitus.

\section{Oxidant-antioxidant system in rat liver and skeletal muscle when exposed to chromium citrate}

The research was conducted on 28 white, vivarium-kept laboratory rats, with body weight varying from 150 to $170 \mathrm{~g}$, and divided into four groups: I the control group, II, III, IV - the research groups. An experimental diabetes mellitus (EDM) was induced by introabdominal injection of Streptozotocin ("Sigma", USA) in $35 \mathrm{mg} / \mathrm{kg}$ bodyweight dosage, after 24-hour fasting. Hyperglycemia was detected using portable glucose meter, by measuring sugar level in the blood taken from the tail vein. Chromium citrate solution in a quantity of 10 and $25 \mathrm{mcg} \mathrm{Cr} 3+/ \mathrm{kg}$ body weight was added to the rations of animals with hyperglycemia in groups III and IV, respectively.

In accordance to ethical principles of experiments on animals used for experimental and scientific purposes, approved by European Convention on vertebrate protection, animals were killed by decapitation in a state of light ether narcosis.

The content of lipid hydroperoxides in a liver and skeletal muscle tissue homogenates was determined by a method that requires protein sedimentation by a trichloroacetic acid (TCA) and further addition of ammonium thiocyanate to the solution ${ }^{7}$. The MDA content was measured by means of a colored reaction of malondialdehyde with the thiobarbituric acid ${ }^{8}$. The activity of superoxide dismutase (SOD, EC 1.1.15.1.) was determined by a

\footnotetext{
${ }^{6}$ Бєленічев І.Ф., Левицький Є.Л., Губський Ю.І. Антиоксидантна система захисту організму : огляд. Сучасні проблеми токсикології. 2002. № 3. С. 24-29.

Дубинина Е.Е. Антиоксидантна система плазми крові. Український біохімічний журнал. 1992. № 64 (2). С. 3-13.

Задоріна О.В. Ферменти антиоксидантної системи печинки щурів за умов отруєння хлоридом кадмію або 1,2-дихлоретаном. Сучасні проблеми токсикологї. 2008. № 3. С. 68-72.

${ }^{7}$ A.s. № 1084681 SSSR, MKY` G № 33/48. Method for determining lypydov hydroperoxides in tissues Biology. Myronchyk V. V. (SSSR). - № 3468369/2813; zayavl. 08.07.82 ; opubl. 07.04.84, Byul. № 13.

8 Коробейникова Э.Н. Модификация определения продуктов перекисного окисления липидов в реакции с тиобарбитуровой кислотой. Лабораторное дело. 1989. № 7. С. 8-9.
} 
method where nitrotetrazolium is reduced by superoxide radicals ${ }^{9}$. Glutathione peroxidase's activity (GP, EC 1.11.1.9.) was measured by the speed of reduced glutathione oxidation ${ }^{10}$. The activity of catalase (EC 1.11.1.6.) was measured by hydrogen peroxide's ability to form a stable colored complex with molybdenum salts ${ }^{11}$.

The activity of glutathione reductase (GR, EC 1.6.4.2) was measured by a speed of glutathione reduction in the presence of NADPH ${ }^{12}$. The content of reduced glutathione was gauged by the level of thionitrophenol anion formation as a result of SH- groups of glutathione and 5,5'-dithiobis(2-nitrobenzoic acid) reaction ${ }^{13}$.

The intensity of free-radicals peroxidation in body depends on various factors, but mainly it is determined by well-coordinated functioning of antioxidant system enzymes. It is established that SOD is one of the most important enzymes in antioxidant system of the body. This enzyme catalyzes the dismutation of superoxide radicals into hydrogen peroxide molecules, which are less reactive. A credible decrease of SOD activity was determined in skeletal muscles (on 25,4\%) in animals from the group II compared to the control group (fig. 1). Nevertheless the activity of this enzyme in skeletal muscle tissue of animals from group III and IV under the condition of chromium citrate addition in a quantity of 10 and $25 \mathrm{mcg}$ was reaching the control level, although there was a tendency to increase compared to the group II. The received results indicate on the corrective properties of exogenous Chromium on the prooxidant - antioxidant balance under the condition of streptozotocin-induced diabetes.

Catalase, which activity correlates with SOD's activity, neutralizes oxygen peroxide that is produced as a result of superoxide radical dismutation. A credible decrease of catalase's activity in liver tissue on $21,5 \%$ and the tendency to its decrease in skeletal muscles, compared to the control group, were determined in animals from group II (fig. 2). Although there was a tendency to increased activity of this enzyme in animals from groups III and IV both in liver and skeletal muscle tissues (except group IV, where those changes were credible) compared to the control group and its credible increase compared to the group II on $22,8 \%$ and $45,8 \%$ in liver tissue and on $57,3 \%$ and $96,7 \%$ in skeletal muscle, respectively. The credible change of enzyme's activity in liver tissue wasn't established during the research.

\footnotetext{
9 Дубиніна Е.С., Сальникова Л.Я., Сфімова Л.Ф. Активність СОД та коферментного діапазону еритроцитів. Лабораторное дело. 1983. № 10. С. 30-33.

${ }_{10}$ Моин В.М. Простой и специфический метод определения активности глутатионпероксидазы в эритроцитах. Лабораторное дело. 1986. № 12. С. 724-72.

${ }^{11}$ Королюк М.А., Иванова Л.К., Майорова И.Г., Токарева В.А. Метод определения активности каталазы. Клиническая лабораторная диагностика. 1988. № 4. С. 44-47.

12 Лабораторні методи досліджень у біології, тваринництві та ветеринарній медицині : довідник / за ред. В.В. Влізло. Львів : СПОЛОМ, 2012.764 с.

${ }^{13}$ Hissin P.J., Hilf R. A fluorometric method for determination of oxidized and reduced glutathione in tissues. Analytical Biochemistry.1976. No. 74. P. 214-226.
} 


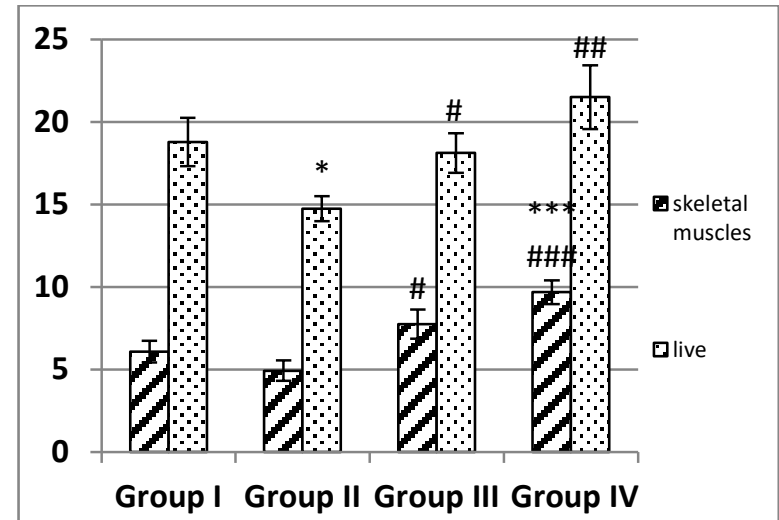

Fig. 1. Catalase activity, $\mathrm{mmol} / \mathrm{min} / \mathrm{mg}$ of protein

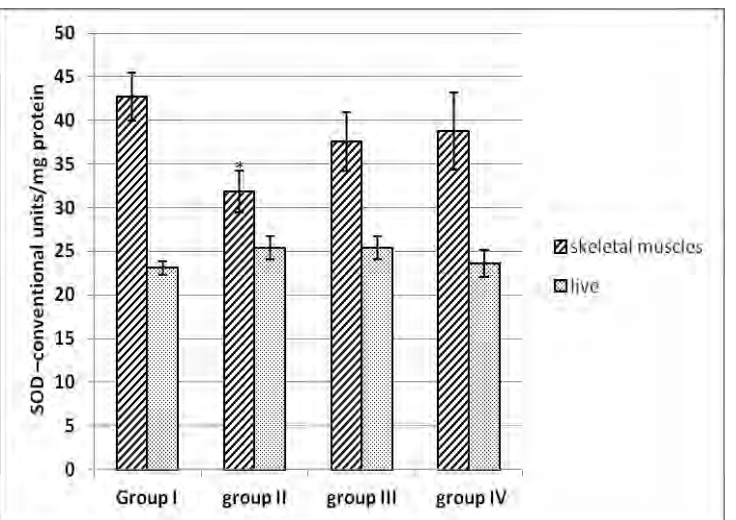

Fig. 2. SOD activity, conventional units/mg of protein $(M \pm m, n=7)$

Notes to these and following figures: ${ }^{*} p<0,05, * * p<0,01, * * * p<0,001-$ probabilities in groups II, III, IV compared to group I; \# $<<0,05$, \#\# $p<0,01$, \#\#\# $<<0,001$ - probabilities in groups III, IV compared to group II

The decrease of SOD and catalase activities in liver and skeletal muscles tissues in rats from diabetic group II indicates on ruinous effect, which causes the accumulation of superoxide radicals $\left(\mathrm{O}_{2}^{-},\right)$, hydrogen peroxide $\left(\mathrm{H}_{2} \mathrm{O}_{2}\right)$ in these tissues ${ }^{14}$. But Chromium addition to the rats' diet facilitates the increase of researched enzymes' activity to the level in the control group. Obviously, it was caused by indirect influence of this element via insulin onto AOS of animals' organisms.

Glutathione system (GS) is especially important in a condition of OS as it directly neutralizes ROS. GS is a "second line defense" after SOD and catalase, it completes the work of the "first line defense" and corrects its mistakes ${ }^{15}$.

Besides catalase, GPx neutralizes oxygen peroxide as well and its affinity to $\mathrm{H} 2 \mathrm{O} 2$ is much higher than catalase's one ${ }^{16}$. GPx activity correlates with reduced glutathione content; its intracellular concentration is maintained by GR. GR function is determined by the level of nicotinamide reduced cofactors. An energetic impoverishment, which causes lack of energetic substrates, is present under the condition of DM. Altogether it affects the defense systems efficiency directly. During the research the GPx activity in liver and skeletal muscles tissues was established to be lower in group II compared to the control group on $20,8 \%$ and $27,5 \%$ respectively. Under the condition of chromium citrate intake resumption of GPx activity was observed in rats with DM (fig. 3,4). GPx activity in liver tissue increased

\footnotetext{
${ }^{14}$ Satheesh M.A., Pari L. Antioxidant effect of Boerhavia diffuse L in tissues of alloxan induced diabetic rats. Indian Journal of Experimental Biology. 2004. No. 42 (10). P. 989-992.

15 Сибірна Н.О., Маєвська О.М., Барська М.Л. Дослідження окремих біохімічних показників за умов оксидативного стресу : навчально-методичний посібник. Львів, 2006. 60 с.

${ }^{16}$ Іванушко Я.Г., Гриневич Ю.П., Липська А.І. Вплив рентгенівського випромінення на ферменти антиокиснювального захисту печінки щурів. Ядерна фізика та енергетика. 2009. С. 76-79.
} 
credibly in groups III and IV on $23,9 \%$ and $37,6 \%$ respectively and in skeletal muscles tissue on $41,7 \%$ and $49,9 \%$ compared to the diabetic group (II).

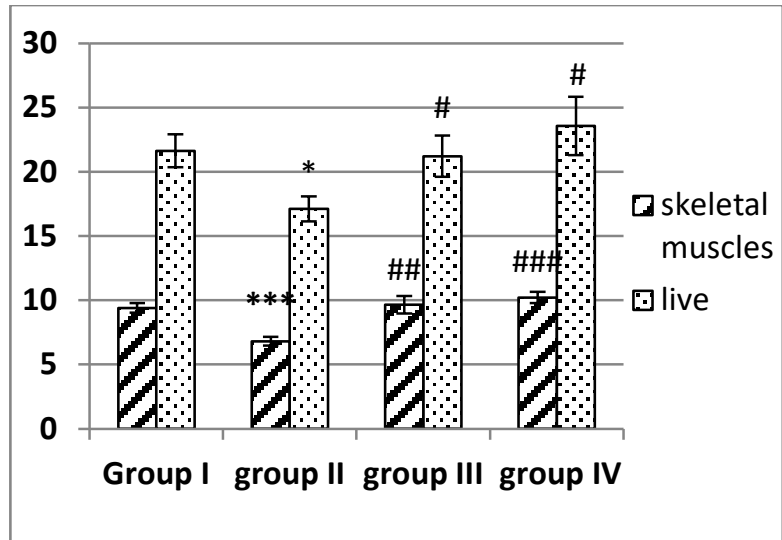

Fig. 3. Activity glutathione peroxidase, $\mu \mathrm{mol} / \mathrm{min} / \mathrm{mg}$ of protein $(\mathbf{M} \pm \mathbf{m}, \mathbf{n}=7)$

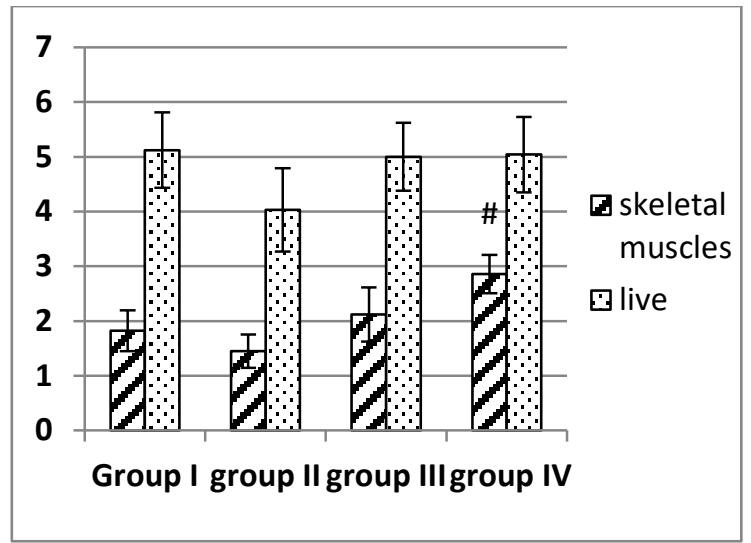

Fig. 4. Activity glutathione reductase, $\mu \mathrm{mol} / \mathrm{min} / \mathrm{mg}$ of protein $(\mathbf{M} \pm \mathbf{m}, \mathbf{n}=7)$

Study of GR in liver tissue showed the tendency to increase in groups III and IV compared to the group II and its normalization compared to the control level. The similar situation appeared during the study of GR in skeletal muscle tissue. But in the group IV the credible decrease almost in two times of the enzyme's activity compared to the group II was observed. Achieved results correspond with data from other researchers, who indicate the activation of the antioxidant defense system after additional intake of chromium citrate ${ }^{17}$.

The activity of GPx corresponds with the concentration of reduced glutathione. The decrease of reduced glutathione content in liver and skeletal muscles tissues was established in rats from group II compared to the control group (fig. 5).

But the content of glutathione reduced was credibly higher in liver and skeletal muscle tissues in rats from groups III and IV compared to the group II on $26 \%$ and $33 \%$ respectively.

Beside that it's worth pointing out much higher concentration of reduced glutathione in the liver compared to skeletal muscles, which is probably related to these tissues' properties. Since the main pool of GSH is synthesized and reduced in the liver ${ }^{18}$.

\footnotetext{
${ }^{17}$ Fernando Guerrero-Romero, Martha Rodriguez-Moran. Complementary Therapies for Diabetes: The case for chromium, Magnesium, and Antioxidants. Archives of Medical Research. 2005. P. 250-257. DOI: 10.1016 / j.arcmed.2005.01.004.

Suzan M. Mansour, Hala F, Zaki and Ezz-El-Din El-Denshary. Chromium picolinate and rossiglitazone improve biochemical derangement in a rat model of inulin resistance. Role of TNF- $£$ and Leptin. Pharmacologia. 2013. No. 4 (3). P. 186-196.

${ }^{18}$ Sieney W., Mielke B., Muller M., et.al. Biomed. Biochem. Acta. 1983. No. 42 (9). P. 1079-1089.
} 


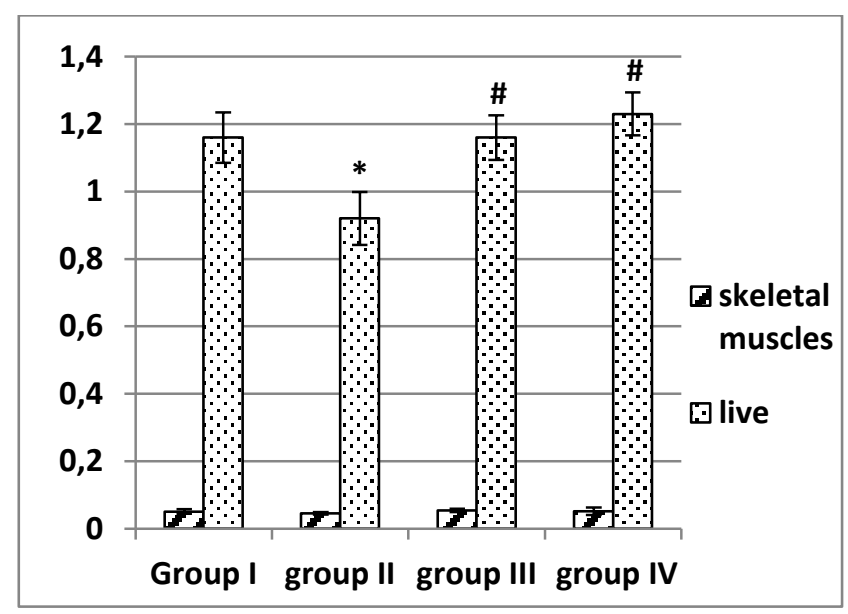

Fig. 5. Contents reduced glutathione, $\mu \mathrm{mol} / \mathrm{mg}$ of protein $(M \pm m, n=7)$

We detected the credible increase of LHP and MDA in tissues of rats with hyperglycemia (group II) compared to rats from the control group (fig. 6, 7). MDA content increases on $75,9 \%$ in skeletal muscles and on $25,2 \%$ in liver homogenate, LHP content increases on $86,3 \%$ and $35,2 \%$ respectively. High lipid peroxidation products content and low activity of antioxidant defense enzymes in liver and skeletal muscle tissue under the condition of Chromium deficiency are related with decreased binding of insulin with cellular receptors. This leads to an excess cortisone activity, which is the antagonist of the insulin, intensifies lipid peroxidation process and inhibits the function of antioxidant system defense $\mathrm{e}^{19}$.

But the Chromium addition to the rats' diet in 10 and $25 \mathrm{mcg} / \mathrm{kg}$ bodyweight dosages led to the decrease of lipid peroxidation products content in studied tissues. In liver tissue of groups III and IV the trend observed in relation to animals in Group II was decreased MDA content, while in skeletal muscles there was a credible decrease of those indexes on $24,3 \%$ and $36 \%$, respectively, compared to group II.

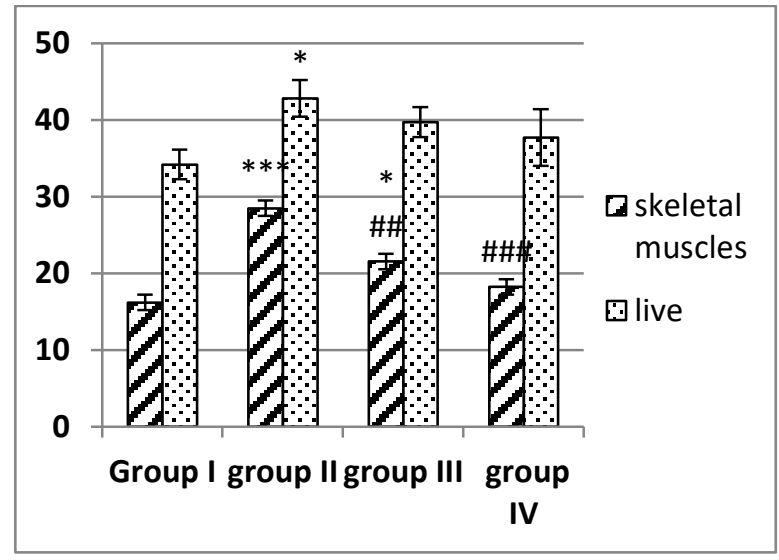

Fig. 6. Contents MDA, nmol/g tissue $(\mathrm{M} \pm \mathbf{m}, \mathbf{n}=\mathbf{7})$

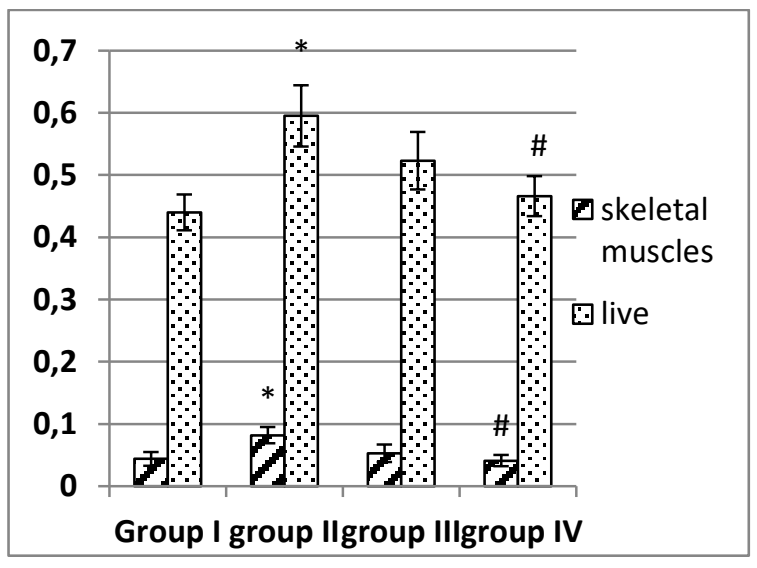

Fig. 7. Contents LHP extinction units $(\mathbf{E U}) / \mathrm{g}$ tissue $(\mathrm{M} \pm \mathrm{m}, \mathrm{n}=7)$

\footnotetext{
${ }^{19}$ National Research Council (NRC). The role of chromium in animal nutrition. Washington, 1995.
} 656 
In liver and skeletal tissues of Group III, the only trend observed in relation to animals in Group II was lowered LHP content. But in group IV this index was credibly lower: on $21,6 \%$ in liver tissue homogenates and on $50 \%$ in skeletal muscle tissue homogenates. Our research corresponds with other researches, where Chromium addition to the rats' diet leads to the decrease of lipid peroxidation processes and the enhancement of insulin effects ${ }^{20}$, which is most likely caused by the activating if insulin membrane receptors ${ }^{21}$.

Increased activity of antioxidant defense system enzymes and reduced glutathione content, decreased MDA and LHP contents indicate the activation of antioxidant system under the condition of chromium citrate addition in a quantity of 10 and $25 \mathrm{mcg} \mathrm{Cr} 3+/ \mathrm{kg}$ body weight to the diet of rats having experimentally-induced diabetes.

\section{Oxidant-antioxidant System in rat liver and skeletal muscle when exposed to zinc and chromium citrates}

The research was implemented on white laboratory rats, which were held in a Institute of Animal Biology NAAS's vivarium. It was completed in accordance to recommendations, approved by European Convention on vertebrate protection, used for experimental and scientific purposes (Strasburg, 1986). Animals with body weight from 150 to $170 \mathrm{~g}$ were divided into three groups, each consisted of 7 animals: I - the control group, II, III research groups. For 30 days of the research rats from the I and II groups received only basic ration, while chromium and zinc citrates solutions were added to the water of animals from group III in $25 \mathrm{mcg} \mathrm{Cr} / \mathrm{kg}$ and $50 \mathrm{mg}$ $\mathrm{Zn} / \mathrm{kg}$ body weight dosage. An experimental diabetes mellitus (EDM) was induced in animals from II and III research groups on the 25th day of the experiment, after 24-hour fasting, by intraperitoneal injection of

\footnotetext{
${ }^{20}$ Іскра Р.Я., Влізло В.В. Біологічна роль хрому в організмі тварин. Біологія тварин. Львів, 2011. № 13 (1-2). С. 69-71.

Іскра Р.Я., Янович В.Г. Біохімічні механізми дії хрому в організмі людини і тварин. Украӥнський біохімічний журнал. 2011. № 83 (5). С. 5-12.

Іскра Р.Я. Методи оцінки системи антиоксидант захисту організму тварин за дії сполук хрому : методічні рекомендації. Львів, 2011.35 с.

Anderson R. Supplemental-chromium effects on glucose, insuline, glucagons and urinary chromium losses in subjects consuming controlled low-chromium diets. Am J Clin Nutr. 1991. № 54 (5). P. 909-916. DOI: $10.1093 / \mathrm{ajcn} / 54.5 .909$.

Julie Martin, Zhong Q. Wang, Xian H. Zhang, et al. Chromium picolinate supplementation attenuates body weight gain and increases insulin sensitivity in subjects with type 2 diabetes. Diabetes Care. 2006. No. 29 (8). P. 1826-1832. 27. DOI: https://doi.org/10.2337/dc06-0254.

Powell S.R. Antioxidant properties of zinc. J. Nutr. 2000. No. 130 P. 1447-1454. DOI: 10.1093/jn/ 130.5.1447S

Ravina A., Slezak L., Mirsky N.N., Bryden A., Anderson R.A. Reversal of corticosteroid-induced diabetes mellitus with supplemental chromium. Diabetic Medicine. 1999. No. 16 (2). P. 164-167. DOI: 10.1046 / j.1464-5491.1999.00004.x.

21 Anderson R.A. Effect of supplemental chromium on patients with symptoms of reactive hypoglycemia. Metabolism: Clinical and Experimental. 1987. No. 36 (4). P. 351-355. DOI: 10.1016/00260495(87)90206-x.
} 
Streptozotocin in $45 \mathrm{mg} / \mathrm{kg}$ bodyweight dosage. Hyperglycemia was detected using portable glucose meter, by measuring sugar level in blood taken from the tail vein. The animals were withdrawn from the experiment by means of decapitation under light ether anesthesia. Materials for the research were homogenates of liver and skeletal muscles, in which the content of lipid peroxidation products and the activity of antioxidant defense enzymes were measured $^{22}$.

The recieved digital data was statistically procecced using a computer program "Statistika". Student's test was used to determine significant difference between averages.

Table 1

\section{The content of lipid peroxidation products and the activity of antioxidant system enzymes in rats' liver in a state of experimental diabetes and under the complex effect of chromium and zinc citrates $(M \pm m, n=7)$}

\begin{tabular}{|l|c|c|c|}
\hline \multirow{2}{*}{\multicolumn{1}{|c|}{ Indexes }} & \multicolumn{3}{|c|}{ Animal groups } \\
\cline { 2 - 4 } & Control & \multicolumn{2}{c|}{ Research } \\
\cline { 2 - 4 } & I & II & III \\
\hline $\begin{array}{l}\text { Lipid hydroperoxides, } \\
\text { standard units/g of protein }\end{array}$ & $0,163 \pm 0,009$ & $0,241 \pm 0,061$ & $0,144 \pm 0,007$ \\
\hline MDA, nmol/g of protein & $3,569 \pm 0,154$ & $4,887 \pm 0,309^{* *}$ & $2,919 \pm 0,090^{* * \# \#}$ \\
\hline $\begin{array}{l}\text { SOD, standard units/mg } \\
\text { of protein }\end{array}$ & $41,882 \pm 1,249$ & $39,375 \pm 1,107$ & $54,22 \pm 1,066^{* * * \# \#}$ \\
\hline $\begin{array}{l}\text { Catalase, mmol/min/mg } \\
\text { of protein }\end{array}$ & $7,57 \pm 0,366$ & $8,77 \pm 0,479$ & $8,817 \pm 0,174^{* *}$ \\
\hline $\begin{array}{l}\text { Reduced glutathione, } \\
\mu \mathrm{mol} / \mathrm{mg} \text { of protein }\end{array}$ & $4,6 \pm 0,326$ & $1,73 \pm 0,062^{* * *}$ & $4,070 \pm 0,166^{\# \# \#}$ \\
\hline $\begin{array}{l}\text { Glutathione peroxidase, } \\
\mu \mathrm{mol} / \mathrm{min} / \mathrm{mg} \text { of protein }\end{array}$ & $9,02 \pm 0,345$ & $6,37 \pm 0,208^{* * *}$ & $10,37 \pm 0,290^{* * \# \# \#}$ \\
\hline $\begin{array}{l}\text { Glutathione reductase, } \\
\mu \mathrm{mol} / \mathrm{min} / \mathrm{mg} \text { of protein }\end{array}$ & $1,53 \pm 0,120$ & $0,818 \pm 0,130^{* * *}$ & $1,310 \pm 0,107^{\# \#}$ \\
\hline
\end{tabular}

\footnotetext{
${ }^{22}$ A.s. № 1084681 SSSR, MKY’ G № 33/48. Method for determining lypydov hydroperoxides in tissues Biology. Myronchyk V. V. (SSSR). - № 3468369/2813; zayavl. 08.07.82 ; opubl. 07.04.84, Byul. № 13.

Коробейникова Э.Н. Модификация определения продуктов перекисного окисления липидов в реакции с тиобарбитуровой кислотой. Лабораторное дело. 1989. № 7. С. 8-9.

Дубиніна Е.С., Сальникова Л.Я., Сфімова Л.Ф. Активність СОД та коферментного діапазону еритроцитів. Лабораторное дело. 1983. № 10. С. 30-33.

Моин ВМ. Простой и специфический метод определения активности глутатионпероксидазы в эритроцитах. Лаб. Дело. 1986; 12: 724-72.

Моин В.М. Простой и специфический метод определения активности глутатионпероксидазы в эритроцитах. Лабораторное дело. 1986. № 12. С. 724-72.

Лабораторні методи досліджень у біології, тваринництві та ветеринарній медицині : довідник / за ред. В.В. Влізло. Львів : СПОЛОМ, 2012.764 с.

Hissin P.J., Hilf R. A fluorometric method for determination of oxidized and reduced glutathione in tissues. Analytical Biochemistry.1976. No. 74. P. 214-226.
} 
The liver maintains the constant glucose blood level. It was established that the content of MDA in rats' liver from group II (tab. 1) was increased in 1,4 times, but the content of reduced glutathione was decreased in 2,7 times, also activities of glutathione peroxidase and glutathione reductase were decreased in 1,4 and 1,9 times respectively. Also the tendency to increased level of lipid hydroperoxides and catalase's activity, while the tendency to decreased level of SOD activity were observed in a researched tissue, compared to animals from the control group, although these changes were not credible. But it was established that the content of MDA in rats' liver from group III was decreased in 1,7 times, but the content of reduced glutathione was increased in 2,3 times, also activities of SOD, glutathione peroxidase and glutathione reductase were increased in 1,4 and 1,6 times respectively, compared with animals from group II. Besides that a credible decrease of MDA content and increase of SOD's, catalase's and glutathione peroxidase's activities were observed, compared to animals from the control group.

It is established that in a physiological state under the clear insulin regulation muscle tissue is one of the main glucose consumers (tab. 2).

Table 2

\section{The content of lipid peroxidation products and the activity of antioxidant system enzymes in rats' muscles in a state of experimental diabetes and under the complex effect of zinc and chromium citrates $(M \pm m, n=7)$}

\begin{tabular}{|l|c|c|c|}
\hline \multirow{2}{*}{\multicolumn{1}{|c|}{ Indexes }} & \multicolumn{3}{|c|}{ Animal groups } \\
\cline { 2 - 4 } & Control & Research \\
\cline { 2 - 4 } & I & II & III \\
\hline $\begin{array}{l}\text { Lipid hydroperoxides, standard } \\
\text { units/g of protein }\end{array}$ & $0,15 \pm 0,005$ & $0,47 \pm 0,048^{* * *}$ & $0,23 \pm 0,054^{\# \#}$ \\
\hline MDA, nmol/g of protein & $1,49 \pm 0,080$ & $2,098 \pm 0,138^{* *}$ & $1,67 \pm 0,129^{\#}$ \\
\hline $\begin{array}{l}\text { SOD, standard units/mg of } \\
\text { protein }\end{array}$ & $63,43 \pm 1,050$ & $51,67 \pm 0,853^{* * *}$ & $67,88 \pm 1,81^{\# \# \#}$ \\
\hline $\begin{array}{l}\text { Catalase, mmol/min/mg of } \\
\text { protein }\end{array}$ & $18,78 \pm 0,972$ & $11,35 \pm 0,319^{* * *}$ & $15,11 \pm 1,078^{* \# \#}$ \\
\hline $\begin{array}{l}\text { Reduced glutathione, } \mu \mathrm{mol} / \mathrm{mg} \\
\text { of protein }\end{array}$ & $0,33 \pm 0,015$ & $0,257 \pm 0,031$ & $0,305 \pm 0,019$ \\
\hline $\begin{array}{l}\text { Glutathione peroxidase, } \\
\mu \mathrm{mol} / \mathrm{min} / \mathrm{mg} \text { of protein }\end{array}$ & $37,3 \pm 2,60$ & $18,68 \pm 0,989 * * *$ & $34,11 \pm 0,809^{\# \#}$ \\
\hline $\begin{array}{l}\text { Glutathione reductase, } \\
\mu \mathrm{mol} / \mathrm{min} / \mathrm{mg} \text { of protein }\end{array}$ & $0,47 \pm 0,045$ & $0,207 \pm 0,008^{* * *}$ & $0,60 \pm 0,061^{\# \# \#}$ \\
\hline
\end{tabular}

We detected a credible increase of lipid hydroperoxides content in 3,1 times, MDA content in 1,4 times, but the decrease of SOD's, catalase's, glutathione peroxidase's and glutathione reductase's activities in 1,2, 1,6, 2,0 
and 2,3 times respectively in the muscle tissue of rats from group II compared to those indexes in animals from the I (control) group.

Since the muscle tissue is an insulin sensitive tissue, in a state of diabetes the speed of glucose phosphorylation to the glucose 6-phosphate is decreased, as a result the intensity of lipolysis rises as well as the content of free unsaturated fatty acids that can be oxidated in a process of lipid peroxidation. The increase of lipid peroxidation products in a state of diabetes is also related to the modification of antioxidant enzymes by the active oxygen and glucose.

With the addition of $\mathrm{Cr}$ and $\mathrm{Zn}$ citrates to rats' ration from group III a decrease of lipid hydroperoxides content in 2,0 times and MDA content in 1,2 times was observed, but the activities of SOD, glutathione peroxidase, glutathione reductase were increased in 1,3,1,8 and 2,9 times respectively, compared to those indexes in animals from group II. Besides that a credible decrease of catalase's activity in 1,2 times was established in group III compared to the group I (control).

\section{CONCLUSIONS}

Overall, the decreased activity of antioxidant defense system enzymes in researched tissues, in animals from group II under the condition of experimental diabetes is conditioned by depletion of their reserves that are consumed for the neutralization of free radicals. The decreased concentration of GSH is related not only with its intensified consumption and insufficient reduction (namely with the change of glutathione peroxidase and glutathione reductase activities) but also with the defection of glutathione synthesis and interchange.

The decrease of lipid hydroperoxides and MDA content in rats tissues from group III under the influence of zinc and chromium citrates indicate the inhibitory effect of researched elements (with the increment usage) on lipid peroxidation processes in blood, liver, muscles and pancreas - organs, that are characterized by a high metabolic activity. The explanation of mechanisms of chromium and zinc inhibitory effect on peroxidation processes in rats' blood and tissues should be sought in the activation of glutathione-dependent antioxidant enzyme system, which neutralizes lipid peroxides and maintains the reduced condition of SH-groups of proteins and therefore assures their functional activity ${ }^{23}$.

Antioxidant effect of $\mathrm{Cr}(\mathrm{III})$ may be conditioned by its ability to regulate expression of antioxidant enzymes' genes ${ }^{24}$. The activation of redox-sensitive genes of antioxidant enzymes that are necessary for the cell defense from

\footnotetext{
${ }^{23}$ Гула Н.М., Горідько Т.М., Стогній Н.А. та ін. Протекторний вплив N-стеароїлетаноламіну за гострої алкогольної інтоксикації у щурів. Український біохімічний журнал. 2010. № 82 (2). С. 42-52.

${ }^{24}$ Chen W.Y., Chen C.J., Liao J.W. Chromium attenuates hepatic damage in a rat model of chronic cholestasis. Life Sciences. 2009. No. 84. P. 606-614. DOI: 10.1016/j.lfs.2009.02.003.
} 
toxic effect of oxidative stress occurs with the aid of active oxygen forms. Main regulatory system in the cell that controls genes expression with the aid of active oxygen forms is presented by MAP(Mitogen-Activated Protein)kinases. Active oxygen forms stimulate a cascade of MAP-kinases and regulate the activity of transcription factors NF-kB, AP-1 i ATF- $2^{25}$. After conducted analysis of literature data and the results of our research we have a basis to affirm that chromium affects the synthesis of antioxidant enzymes by the means of MAP-kinases' activity regulation. Besides that, the activity of antioxidant system enzymes may change because of Chromium effect on cofactors content and physiological accessibility.

One of important Zinc functions is its participation in antioxidant defense system $^{26}$. Zinc can activate synthesis of $\mathrm{Cu} / \mathrm{Zn}$ - dependent SOD in liver ${ }^{27}$. Zinc can compete with Iron and Copper, as its antagonists, for connections with cell membranes and reduce free radicals formation, hence implement a direct antioxidant effect ${ }^{28}$. Also, Zinc can protect SH-groups of proteins by means of direct connection with them or by dimensional hindering for binding with any other protein sites that are in a close proximity to SH-groups. Zinc has the ability to lessen the damage of cells that already have elements of sitespecific oxidative damage.

Despite that proves of antioxidant properties of $\mathrm{Zn}$ and $\mathrm{Cr}$ are persuasive, the exact mechanisms are still recondite. Further researches will allow to reveal mechanisms of antioxidant properties of $\mathrm{Cr}$ and $\mathrm{Zn}$ better and this will provide an opportunity to ascertain new properties of organic compounds of these microelements and to elaborate new medication for the prevention and treatment of diabetes mellitus.

\section{SUMMARY}

Since the diabetes mellitus is a genetically predetermined disease, preventive measures to postpone the onset of the disease or to avert its appearance are especially important for people from risk group. That is why it is so important to evaluate role of some microelements in diabetes prevention. In particular, it is known that zinc plays an important role in insulin synthesis,

25 Турпаев К.Т. Активные формы кислорода и регуляция экспресии генов. Биохимия. 2002. № 67 (3). C. 339-352.

${ }^{26}$ Bun S.D., Guo Y.M., Guo F.C., Ji F.J., Cao H. Influence of organic zinc supplementation on the antioxidant status and immune responses of broilers challenged with Eimeria tenella. Poultry Science. 2011. No. 90 (6). P. 1220-1226. DOI: 10.3382 / ps.2010-01308.

Powell S.R. Antioxidant properties of zinc. J. Nutr. 2000. No. 130 P. 1447-1454. DOI: 10.1093/jn/ 130.5.1447S.

${ }^{27}$ Kulikowska-Karpińska E., Moniuszko-Jakoniuk J. Lead and Zinc Influence on Antioxidant Enzyme Activity and Malondialdehyde Concentrations. Polish Journal of Environmental Studies. 2001. No. 10 (3). P. 161-165.

${ }^{28}$ Tate D.J., Miceli M.V., Newsome D.A. Zinc protects against oxidative damage in cultured human retinal pigment epithelial cells. Free Radic. Biol. Med. 1999. No. 26. P. 704-713. DOI: 10.1016 / s0891-5849 (98) 00253-6. 
accumulation and release by $\beta$-cells in pancreas, while its synergist chromium activates insulin receptors on cell membranes.

Therefore, the aim of our research was to establish the effect of chromium and zinc citrates on the functioning of antioxidant system and on the content of lipid peroxidation products in rats' blood and tissues under the condition of experimental streptozotocin-induced diabetes mellitus. Experiments were conducted on white laboratory rats which were divided into groups: I - the control group, II, III, IV - research groups. Rats from the I and II group received only basic ration, while chromium and zinc citrates solutions

An experimental diabetes mellitus (EDM) was induced in animals from II and III research groups on the 25th day of the experiment, after 24-hour fasting, by intraperitoneal injection of Streptozotocin in $45 \mathrm{mg} / \mathrm{kg}$ bodyweight dosage. Materials for the research were rats' tissues that were received after decapitation.

The content of lipid hydroperoxides in tissues was determined by a method that requires protein sedimentation by a trichloroacetic acid (TCA) and further addition of ammonium thiocyanate to the solution. The MDA content was measured by means of a colored reaction of malondialdehyde with the thiobarbituric acid. The activity of superoxide dismutase (SOD,EC 1.1.15.1.) was determined by a method where nitrotetrazolium is reduced by superoxide radicals. Glutathione peroxidase's activity (GP, EC 1.11.1.9.) was measured by the speed of reduced glutathione oxidation. The activity of catalase (EC 1.11.1.6.) was measured by hydrogen peroxide's ability to form a stable colored complex with molybdenum salts. The activity of glutathione reductase (GR, EC 1.6.4.2) was measured by a speed of glutathione reduction in the presence of NADPH. The content of reduced glutathione was gauged by the level of thionitrophenol anion formation as a result of SH-groups of glutathione and 5,5'-dithiobis-(2-nitrobenzoic acid) reaction.

It was determined during the research that lipid hydroperoxides (LHP) and MDA contents in rats' tissues were increased, while the activity of antioxidant defense system enzymes and reduced glutathione content were decreased under the condition of streptozotocin-induced DM. Under the condition of combined chromium and zinc citrates addition to the diet of rats from we observed the credible decrease of lipid hydroperoxides content, while the increased activity of antioxidant enzymes compared to those indexes from group II.

The received results indicate the normalization of lipids peroxidation processes and antioxidant defense under the influence of chromium and zinc citrates in animals with hyperglycemia. The further research of antioxidant properties of organic compounds of these microelements will let to develop medical remedies for diabetes prevention and treatment. 


\section{REFERENCES}

1. A.s. № 1084681 SSSR, MKY` G № 33/48. Method for determining lypydov hydroperoxides in tissues Biology. Myronchyk V. V. (SSSR). № 3468369/2813; zayavl. 08.07.82 ; opubl. 07.04.84, Byul. № 13.

2. Anderson R. Supplemental-chromium effects on glucose, insuline, glucagons and urinary chromium losses in subjects consuming controlled low-chromium diets. Am J Clin Nutr. 1991. № 54 (5). P. 909-916. DOI: 10.1093/ajen/54.5.909.

3. Anderson R.A. Effect of supplemental chromium on patients with symptoms of reactive hypoglycemia. Metabolism: Clinical and Experimental. 1987. No. 36 (4). P. 351-355. DOI: 10.1016/0026-0495(87)90206-x.

4. Brownlee M. The pathobiology of diabetic complications: a unifying mechanism. Diabetes. 2005. No. 54 (6). P. 1615-1625. DOI: 10.2337/diabetes. 54.6.1615.

5. Bun S.D., Guo Y.M., Guo F.C., Ji F.J., Cao H. Influence of organic zinc supplementation on the antioxidant status and immune responses of broilers challenged with Eimeria tenella. Poultry Science. 2011. No. 90 (6). P. 1220-1226. DOI: 10.3382 / ps.2010-01308.

6. Chen W.Y., Chen C.J., Liao J.W. Chromium attenuates hepatic damage in a rat model of chronic cholestasis. Life Sciences. 2009. No. 84. P. 606-614. DOI: $10.1016 /$ j.lfs.2009.02.003.

7. Julie Martin, Zhong Q. Wang, Xian H. Zhang, et al. Chromium picolinate supplementation attenuates body weight gain and increases insulin sensitivity in subjects with type 2 diabetes. Diabetes Care. 2006. No. 29 (8). P. 1826-1832. 27. DOI: https://doi.org/10.2337/dc06-0254.

8. Fernando Guerrero-Romero, Martha Rodriguez-Moran. Complementary Therapies for Diabetes: The case for chromium, Magnesium, and Antioxidants. Archives of Medical Research. 2005. P. 250-257. DOI: $10.1016 /$ j.arcmed.2005.01.004.

9. Hissin P.J., Hilf R. A fluorometric method for determination of oxidized and reduced glutathione in tissues. Analytical Biochemistry.1976. No. 74. P. 214-226.

10. Kulikowska-Karpińska E., Moniuszko-Jakoniuk J. Lead and Zinc Influence on Antioxidant Enzyme Activity and Malondialdehyde Concentrations. Polish Journal of Environmental Studies. 2001. No. 10 (3). P. 161-165.

11. Martyn J.A., Kaneki M., Yasuhara S. Obesity-induced insulin resistance and hyperglycemia: etiologic factors and molecular mechanisms. Anesthesiology. 2008. No. 109 (1). P. 137-148. DOI: 10.1097/ALN. 0b013e3181799d45.

12. National Research Council (NRC). The role of chromium in animal nutrition. Washington, 1995. 
13. Pacher P., Beckman J.S., Liaudet L. Nitric oxide and peroxynitrite in health and disease. Physiol. 2007. No. 87 (1). P. 315-424. DOI: 10.1152/ physrev. 00029.2006.

14. Powell S.R. Antioxidant properties of zinc. J. Nutr. 2000. No. 130 P. 1447-1454. DOI: 10.1093 / jn / 130.5.1447S.

15. Ravina A., Slezak L., Mirsky N.N., Bryden A., Anderson R.A. Reversal of corticosteroid-induced diabetes mellitus with supplemental chromium. Diabetic Medicine. 1999. No. 16 (2). P. 164-167. DOI: 10.1046 / j.1464-5491.1999.00004.x.

16. Satheesh M.A., Pari L. Antioxidant effect of Boerhavia diffuse L in tissues of alloxan induced diabetic rats. Indian Journal of Experimental Biology. 2004. No. 42 (10). P. 989-992.

17. Sieney W., Mielke B., Muller M., et.al. Biomed. Biochem. Acta. 1983. No. 42 (9). P. 1079-1089.

18. Suzan M. Mansour, Hala F, Zaki and Ezz-El-Din El-Denshary. Chromium picolinate and rossiglitazone improve biochemical derangement in a rat model of inulin resistance. Role of TNF- $£$ and Leptin. Pharmacologia. 2013. No. 4 (3). P. 186-196.

19. Tate D.J., Miceli M.V., Newsome D.A. Zinc protects against oxidative damage in cultured human retinal pigment epithelial cells. Free Radic. Biol. Med. 1999. No. 26. P. 704-713. DOI: 10.1016/s0891-5849 (98) 00253-6.

20. Бєленічев І.Ф., Левицький Є.Л., Губський Ю.І. Антиоксидантна система захисту організму : огляд. Сучасні проблеми токсикологіï. 2002. № 3. C. 24-29.

21. Лабораторні методи досліджень у біології, тваринництві та ветеринарній медицині : довідник / за ред. В.В. Влізло. Львів : СПОЛОМ, 2012.764 c.

22. Гула Н.М., Горідько Т.М., Стогній Н.А. та ін. Протекторний вплив N-cтеароїлетаноламіну за гострої алкогольної інтоксикації у щурів. Украӥнський біохімічний журнал. 2010. № 82 (2). С. 42-52.

23. Дрель В.Р. Основні механізми виникнення та розвитку діабетичних ускладнень: роль нітративного стресу. Biol. Stud. 2010. № 4 (2). P. 141-158 DOI: https://doi.org/10.30970/sbi.0402.085.

24. Дубинина Е.Е. Антиоксидантна система плазми крові. Украӥнський біохімічний журнал. 1992. № 64 (2). С. 3-13.

25. Дубиніна Е.С., Сальникова Л.Я., Єфімова Л.Ф. Активність СОД та коферментного діапазону еритроцитів. Лабораторное дело. 1983. № 10. C. 30-33.

26. Задоріна О.В. Ферменти антиоксидантної системи печинки щурів за умов отруєння хлоридом кадмію або 1,2-дихлоретаном. Сучасні проблеми токсикологіï. 2008. № 3. С. 68-72. 
27. Іванушко Я.Г., Гриневич Ю.П., Липська А.І. Вплив рентгенівського випромінення на ферменти антиокиснювального захисту печінки щурів. Ядерна фізика та енергетика. 2009. С. 76-79.

28. Іскра Р.Я., Влізло В.В. Біологічна роль хрому в організмі тварин. Біологія тварин. Львів, 2011. № 13 (1-2). С. 69-71.

29. Іскра Р.Я., Янович В.Г. Біохімічні механізми дії хрому в організмі людини і тварин. Украӥнський біохімічний журнал. 2011. № 83 (5). С. 5-12.

30. Іскра Р.Я. Методи оцінки системи антиоксидант захисту організму тварин за дії сполук хрому : методічні рекомендації. Львів, 2011. 35 с.

31. Коробейникова Э.Н. Модификация определения продуктов перекисного окисления липидов в реакции с тиобарбитуровой кислотой. Лабораторное дело. 1989. № 7. С. 8-9.

32. Королюк М.А., Иванова Л.К., Майорова И.Г., Токарева В.А. Метод определения активности каталазы. Клиническая лабораторная диагностика. 1988. № 4. С. 44-47.

33. Кузишин О.В., Ковалишин Н.В., Алмашина Х.В. Біохімія цукрового діабету: 1. Теоретична частина (огляд). Медична хімія. 2010. C. $74-115$.

34. Моин В.M. Простой и специфический метод определения активности глутатионпероксидазы в эритроцитах. Лабораторное дело. 1986. № 12. C. 724-72.

35. Сибірна Н.О., Маєвська О.М., Барська М.Л. Дослідження окремих біохімічних показників за умов оксидативного стресу : навчальнометодичний посібник. Львів, 2006. 60 с.

36. Турпаев К.Т. Активные формы кислорода и регуляция экспресии генов. Биохимия. 2002. № 67 (3). С. 339-352.

Information about authors: Slivinska O. M.,

Assistant at the Department of Laboratory Medicine Higher Educational Communal Institution of Lviv Regional Council "Andrey Krupynsky Lviv Medical Academy" 72, Doroshenko str., Lviv, 79000, Ukraine

Iskra R. Ya.,

Doctor of Biological Sciences, Head of the Laboratory of Biochemistry Adaptation and Ontogenesis of Animals Institute of Animal Biology of the National Academy of Agrarian Sciences of Ukraine 38, V. Stusa str., Lviv, 79034, Ukraine 